\title{
Restrukturyzacja polskiego przemysłu środków transportu szynowego na przykładzie przedsiębiorstwa Pojazdy Szynowe PESA Bydgoszcz SA
}

Każde przedsiębiorstwo w swej działalności przechodzi przez etapy koniunktury i dekoniunktury. Dekoniunktura może być skutkiem różnorodnych czynników o charakterze wewnętrznym (np. utrata płynności finansowej spowodowana zbyt niskim poziomem kapitału obrotowego, nadmierna skala prowadzonej działalności gospodarczej) i/lub zewnętrznym (np. rosnąca konkurencja na rynku krajowym i zagranicznym, zmiany w popycie rynkowym). W skrajnym przypadku, gdy wielkość zadłużenia przewyższa wartość majątku przedsiębiorstwa, może ono zostać postawione w stan upadłości.

W przeciwdziałaniu tej niekorzystnej tendencji istotną rolę odgrywa restrukturyzacja przedsiębiorstwa w obszarach: techniki i technologii, organizacji i zarządzania, ekonomiki i rynku oraz organizacyjno-prawnym. Jej efektem jest poprawa zdolności konkurencyjnej przedsiębiorstwa (np. szybkie reagowanie na zmiany w otoczeniu, lepsze wykorzystanie zasobów własnych) oraz jego pozycji konkurencyjnej (np. zwiększenie udziału w rynku).

Współcześnie restrukturyzacja jest realizowana w sposób ciągły w każdym przedsiębiorstwie, czyli jest stałym elementem strategii jego rozwoju. Wymusza ją rosnąca konkurencja między przedsiębiorstwami towarzysząca nowemu systemowi gospodarowania, integracji europejskiej i nasilającemu się procesowi globalizacji. W spółkach kapitałowych dodatkowo wymuszają ją naciski akcjonariuszy/udziałowców zainteresowanych wzrostem wartości rynkowej przedsiębiorstwa oraz wzrostem stopy zainwestowanego kapitału.

Jednym z rodzimych przykładów pomyślnie przeprowadzonej restrukturyzacji przedsiębiorstwa jest PESA Bydgoszcz S.A., które z jednego z wielu krajowych zakładów naprawiających tabor kolejowy dla PKP, stało się wiodącym polskim producentem pojazdów szynowych, obecnie wkraczającym na rynki krajów Europy Zachodniej.

Transformacja gospodarcza lat 90 . XX w. była dla sektora kolejowego bardzo trudna. Zapaść związana ze spadkiem zapotrzebowania na przewozy oraz wewnętrzne niedostosowanie Polskich Kolei Państwowych do realiów wolnego rynku dotknęła również firmy, które w minionym systemie gospodarczym były ściśle powiązane z transportem kolejowym, a więc producentów lokomotyw i wagonów oraz przedsiębiorstw zajmujących się naprawami taboru.

Zakłady Naprawcze Taboru Kolejowego w Bydgoszczy przed rokiem 1989 posiadały w skali całej swojej branży jasno określone zadania, tj. naprawy lokomotyw parowych 
i spalinowych oraz wagonów towarowych, choć na tle innych ZNTK wachlarz ten był i tak szeroki, zazwyczaj bowiem podobne przedsiębiorstwa miały bardzo wąskie specjalizacje, np. naprawa lokomotyw elektrycznych wybranych serii. M.in. dzięki temu pozycja konkurencyjna ZNTK Bydgoszcz była korzystniejsza niż w przypadku innych zakładów. W 1988 roku w przedsiębiorstwie zatrudnionych było ok. 3000 pracowników.

Zdecydowane kroki służące dalszej dywersyfikacji oferty firmy w realiach rodzącego się wówczas wolnego rynku podjęto na samym początku lat 90. ubiegłego wieku. Zakład rozpoczął realizację dla PKP napraw elektrycznych zespołów trakcyjnych (EZT), wagonów pasażerskich (kuszetek, 1 i 2 klasy) oraz zespołów trakcyjnych WKD. Do 1995 roku pojawił się również nowy ważny segment działalności - modernizacja wagonów sypialnych dla kolei polskich oraz krajów byłego ZSRR (Litwy i Białorusi).

Stopniowa reorganizacja zakładu rozpoczęła się w 1991 roku wraz z wyłączeniem go ze struktur PKP. W 1995 r. przedsiębiorstwo przekształcono w spółkę akcyjną w celu wprowadzenia jej do NFI. Ówczesna sytuacja sektora kolejowego w Polsce była bardzo zła - PKP ograniczały drastycznie ofertę przewozową, brakowało również środków finansowych na naprawy i modernizację taboru kolejowego, stąd ZNTK Bydgoszcz znalazły się na granicy upadłości. Zatrudnienie w latach 1997-2000 spadło z 1900 do 900 osób, w 1997 roku strata firmy wyniosła $19 \mathrm{mln}$ zł przy osiagniętych przychodach na poziomie $68 \mathrm{mln} \mathrm{zł}$.

W związku z brakiem pomysłu NFI odnośnie do przyszłości spółki, w sytuacji gdy nie było chętnych na jej zakup, jak również w obawie przed nieuczciwymi inwestorami, zainteresowanymi wyprowadzaniem kapitału z firmy i doprowadzeniem jej do upadłości, podjęto niezwykle ryzykowną decyzję o wykupie przedsiębiorstwa przez jego menedżerów (za własne środki oraz zaciągnięte kredyty), którzy uprzednio uzyskali zgodę załogi oraz zakładowych związków zawodowych. W międzyczasie na bazie majątku przedsiębiorstwa wyodrębniano mniejsze spółki. Działania te stanowiły bardzo silny bodziec do utrzymania zakładu na rynku, gdyż od momentu prywatyzacji według wybranego modelu zarządzającywłaściciele podejmując decyzje w firmie rzucali na szalę swój osobisty los. To wówczas nawiązano bardzo korzystną dla przedsiębiorstwa współpracę z kolejami ukraińskimi oraz rozpoczęto przebudowę wojskowych wagonów towarowych na wagony przystosowane do przewozu zboża. Ważnym elementem strategii restrukturyzacyjnej stało się nastawienie na tworzenie kadry pracowników z wyższym wykształceniem i odpowiednimi kwalifikacjami.

Ważnym momentem w dziejach spółki był przełom wieków XX/XXI. Restrukturyzacja PKP, która w dziedzinie pasażerskich przewozów regionalnych przesunęła odpowiedzialność za ten segment działalności kolejowej w kierunku samorządów wojewódzkich, stanowiła punkt wyjścia do podjęcia działań firmy zmierzających ku produkcji pojazdów szynowych. Liczono bowiem, iż ta część rynku taborowego, będąca w Polsce od blisko 10 lat w stagnacji, zostanie wzorem innych państw europejskich na nowo odkryta. Szczególne nadzieje upatrywano w lekkich spalinowych wagonach silnikowych, zwanych autobusami szynowymi, które miały być alternatywą dla niezwykle kosztochłonnych tradycyjnych zestawów lokomotywa + wagony oraz swoistym panaceum na proces likwidacji połączeń kolejowych na liniach o charakterze lokalnym. W latach 2000-2001 rozpoczęto pracę nad nowym pojazdem szynowym „Partner”. Jednocześnie podjęto szereg działań zmierzających do zmiany wizerunku firmy, ukazujących jej wejście na rynek producentów. Nacechowaną negatywnymi skojarzeniami nazwę Zakłady Naprawcze Taboru Kolejowego zmieniono na Pojazdy Szynowe PESA Bydgoszcz Spółka Akcyjna Holding (PESA). Jak się później okazało, był to bardzo korzystny zabieg - firmie dosyć szybko udało się zerwać z wizerunkiem 
siermiężnego ZNTK, szczególnie wśród kontrahentów zachodnioeuropejskich, dla których znakiem rozpoznawczym przedsiębiorstwa jest wyłącznie nazwa i logo PESA. W tym czasie spółka znalazła się w ministerialnym wykazie producentów taboru kolejowego, dzięki czemu - obok ZNTK Poznań oraz Kolzam Racibórz, miała możliwość dostarczania części szynobusów, zakupionych przez samorządy wojewódzkie za środki przekazane na ten cel przez rząd. Dzięki przeprowadzonej restrukturyzacji firmie udało się wejść na ścieżkę rozwoju - zatrudnienie w roku 2001 przekroczyło poziom 1500 osób.

W 2001 roku zaprezentowano pierwszy autobus szynowy typu 214M „Partner”, którego właścicielem stał się Urząd Marszałkowski Województwa Kujawsko-Pomorskiego. W okresie następnych kilku lat, gdy ,wykaz producentów” przestał istnieć, a zakup taboru kolejowego przez samorządy (możliwy głównie dzięki dostępności środków wsparcia z funduszy unijnych) odbywał w trybie zamówień publicznych, okazało się, że PESA szybko uporała się ze swoimi rodzimymi konkurentami i właściwie zmonopolizowała krajowy rynek produkcji wagonów silnikowych oraz zespołów trakcyjnych (spalinowych oraz elektrycznych). Rozwijane przez firmę produkty, przechodząc przez kolejne etapy poprawek i unowocześnień (sekwencja serii pojazdów spalinowych i elektrycznych SA106, SA103, EN95, EN81, SA131, SA132, SA133, SA134, SA135, ATR220; EN95, EN81, ED59, ED74), pozwalają zaliczyć PESE do grona producentów wyrobów nie tylko tanich, ale i coraz bardziej solidnych. Z różnych bowiem powodów (także z winy użytkowników) prototypowe produkty PESY charakteryzują się stosunkowo wysoką awaryjnością. Poniżej przedstawiono zestawienie kolejowych pojazdów pasażerskich wyprodukowanych przez PESĘ.

Tab. 1. Kolejowe pojazdy pasażerskie wyprodukowane w zakładach PESA Bydgoszcz (stan na grudzień 2008)

\begin{tabular}{|c|c|c|c|}
\hline Seria & $\begin{array}{l}\text { Lata produkcji } \\
\text { (przekazanie } \\
\text { odbiorcom) }\end{array}$ & $\begin{array}{c}\text { Liczba wyprodukowanych } \\
\text { egzemplarzy }\end{array}$ & Odbiorcy \\
\hline \multicolumn{4}{|c|}{ tabor spalinowy } \\
\hline SA106 & 2002-2006 & 19 & $\begin{array}{l}\text { woj. kujawsko-pomorskie } \\
\text { woj. warmińsko-mazurskie } \\
\text { woj. dolnośląskie }\end{array}$ \\
\hline SA103 & od 2005 & 13 & $\begin{array}{l}\text { woj. podkarpackie } \\
\text { woj. lubelskie } \\
\text { woj. opolskie } \\
\text { woj. pomorskie } \\
\text { woj. zachodniopomorskie }\end{array}$ \\
\hline SA131 & 2005 & 1 & woj. pomorskie \\
\hline SA132 & od 2005 & 15 & $\begin{array}{l}\text { woj. dolnośląskie } \\
\text { woj. wielkopolskie } \\
\text { woj. pomorskie }\end{array}$ \\
\hline SA133 & od 2006 & 8 & $\begin{array}{l}\text { woj. podlaskie } \\
\text { woj. lubuskie } \\
\text { woj. małopolskie }\end{array}$ \\
\hline SA134 & od 2007 & 8 & $\begin{array}{l}\text { Arriva PCC } \\
\text { woj. dolnośląskie } \\
\text { woj. opolskie } \\
\end{array}$ \\
\hline SA135 & od 2008 & 3 & woj. dolnośląskie \\
\hline
\end{tabular}




\begin{tabular}{|c|c|c|l|}
\hline $610 \mathrm{M}$ & 2004 & 1 & koleje ukraińskie UZ \\
\hline $620 \mathrm{M}$ & od 2004 & $8(\mathrm{z} \mathrm{10})$ & $\begin{array}{l}\text { koleje ukraińskie UZ } \\
\text { koleje litewskie LG }\end{array}$ \\
\hline ATR220 & od 2008 & $6(\mathrm{z} 23)$ & Ferrovie del Sud Est (Apulia) \\
\hline \multicolumn{3}{|c|}{ tabor elektryczny } \\
\hline EN95 & 2004 & 1 & PKP WKD (obecnie WKD) \\
\hline EN81 & od 2005 & 8 & $\begin{array}{l}\text { woj. świętokrzyskie } \\
\text { woj. małopolskie }\end{array}$ \\
\hline ED59 & 2006 & 1 & woj. łódzkie \\
\hline ED74 & od 2006 & 14 & $\begin{array}{l}\text { PKP Przewozy Regionalne } \\
\text { (użytkowane przez PKP Intercity) }\end{array}$ \\
\hline
\end{tabular}

Źródło: opracowanie własne, m. in. na podstawie pl.wikipedia.org, hasła: „lista wagonów silnikowych PKP”, „lista zespołów trakcyjnych PKP"1

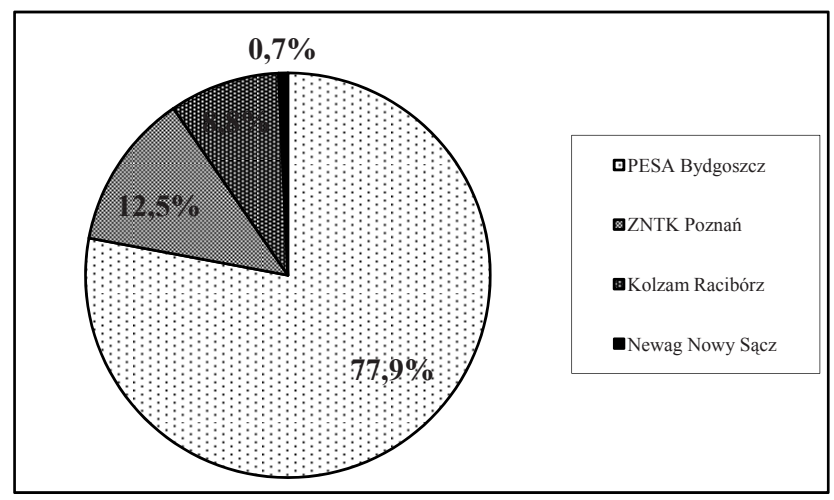

Ryc. 1. Udział przedsiębiorstwa PESA Bydgoszcz w krajowej produkcji nowego taboru dla kolejowych przewozów pasażerskich (stan na grudzień 2008 r.)

Należy dodać, iż przestawione dane będą ulegały zmianie, w chwili obecnej trwa bowiem realizacja zamówień m.in. dla Regionu Apulia (ATR220), województwa opolskiego (SA134) oraz województwa kujawsko-pomorskiego (5 wagonów doczepnych do szynobusów serii SA106). Ponadto w związku pulą środków finansowych będących w posiadaniu samorządów wojewódzkich w ramach Regionalnych Programów Operacyjnych na lata 2007-2013 w najbliższym czasie pojawią się kolejne zamówienia na tabor pasażerski, których prawdopodobnym zleceniobiorcą będzie PESA. Obecny blisko 80\% udział w krajowej produkcji pasażerskiego taboru kolejowego w najbliższych kilku latach przypuszczalnie nie będzie się zmniejszał.

Dotychczas na krajowym rynku w większości przypadków czynnikiem decydującym o wyborze producenta nowego taboru do przewozów regionalnych była cena, dlatego każdy renomowany zagraniczny dostawca w rywalizacji z PESA pozbawiony był szans. Ta kwestia z kolei odbiła się w jakimś sensie na jakości produkowanego taboru, szczególnie w zakresie komfortu podróżnych. Urzędy marszałkowskie, dla których inwestycje w zakresie taboru kolejowego stanowiły zupełnie nową sferą działalności, tworząc specyfikacje do kolejnych prze-

${ }^{1}$ Z reguły odradza się traktowania Wikipedii jako rzetelnego źródła wiedzy naukowej i informacji, jednakże w kwestii inwentaryzacji określonych typów polskiego taboru kolejowego przedstawione dane, po weryfikacji przez autorów, uznano za poprawne, wyczerpujące i miarodajne w danym momencie czasowym. 
targów na zakup autobusów szynowych z reguły koncentrowały się na zapisach minimalizujących koszty - stąd na przykład pierwsze serie pojazdów wszystkich krajowych producentów wyposażone są w niewygodne, twarde siedzenia. Popełniono również wiele błędów związanych z nieprecyzyjnym lub nieprzemyślanymi zapisami w specyfikacjach, które wykonawca musiał zrealizować zgodnie z wolą zamawiającego. Najbardziej nagłośnionym medialnie przykładem takiej sytuacji były niewygodne i zbyt ciasno ułożone siedzenia w zespołach trakcyjnych ED74 przeznaczonych do kursowania na trasie Warszawa-Łódź, wyprodukowanych przez PESA na zamówienie PKP Przewozy Regionalne, które zdaniem podróżnych nadają się bardziej do ruchu podmiejskiego niż do połączeń międzyaglomeracyjnych.

Z punktu widzenia urzędów marszałkowskich - dominującej grupy właścicieli większości nowych produktów bydgoskiej firmy - głównym obecnie problemem jest niejako „monopolistyczna” pozycja przedsiębiorstwa na rodzimym rynku. Większość napraw bieżących i wszystkie przeglądy okresowe muszą się odbywać w zakładach w Bydgoszczy (zapisy gwarancyjne, brak alternatywnych lokalizacji), co w przypadku jednego pojazdu oznacza każdorazowe wyłączenie z eksploatacji na okres od kilku dni do kilku tygodni. W kontekście dużej awaryjności pierwszych serii pojazdów sytuacja taka jest uciążliwa zarówno dla przewoźnika, jak i właściciela taboru. Przedstawiciele niektórych urzędów marszałkowskich zwracają również uwagę, iż w początkowych latach funkcjonowania na rynku PESA wykazywała zbyt małą wrażliwość w zakresie standardu swych produktów - brak precyzyjnych zapisów w specyfikacjach dotyczących rozwiązań technicznych lub wyposażenia pojazdów firma interpretowała na swoją korzyść (minimalizacja kosztów), co powodowało, że chociaż wyprodukowany tabor był zgodny z zamówieniem, nie do końca spełniał oczekiwania samorządu. $Z$ drugiej jednak strony trudno dziwić się producentowi, że nie zamierza ponosić dodatkowych kosztów, np. zakupu i montażu wygodniejszych siedzeń czy innych elementów wyposażenia pojazdu, jeśli nie ma takiego wymogu po stronie nabywcy. Jest to podstawowa strategia marketingowa dla każdego przedsiębiorcy - szczególnie w początkowej fazie jego obecności w danym segmencie rynku.

Warto jednak zauważyć, iż w rywalizacji z innymi rodzimymi producentami to PESA zdobyła pozycję dominująca, także za sprawą jakości swoich wyrobów. Zarówno ZNTK Poznań jak i Kolzam Racibórz nie udźwignęły ciężaru walki konkurencyjnej - w obu przypadkach jedną z przyczyn zaprzestania produkcji były porażki lub brak uczestnictwa w przetargach, które wygrywała PESA.

W międzyczasie firma rozwinęła swą działalność w innych segmentach rynku pojazdów szynowych, podjęła produkcję tramwajów wysoko- i niskopodłogowych, specjalistycznych wagonów towarowych oraz wagonów sypialnych standardu Euronight, utrzymując jednocześnie ważną na polskim rynku pozycję zakładu wykonującego naprawy okresowe i modernizacje lokomotyw spalinowych, wagonów pasażerskich (wszystkie rodzaje), w tym wagonów sypialnych dla kolei ukraińskich, rosyjskich, litewskich, białoruskich, oraz elektrycznych zespołów trakcyjnych. $\mathrm{Z}$ racji swojego położenia oraz konkurencyjnej cenowo oferty firma wykonuje również naprawy lokomotyw spalinowych operatorom niemieckim. Jedynym segmentem działalności zarzuconym w procesie restrukturyzacji jest naprawa wagonów towarowych.

Obecnie oferta PESA kształtuje się następująco:

- produkcja i naprawy autobusów szynowych oraz zespołów trakcyjnych (spalinowych i elektrycznych) dla ruchu regionalnego, aglomeracyjnego oraz lokalnego,

- produkcja tramwajów (dla Elbląga, Bydgoszczy, Warszawy), 
- naprawy i modernizacje wagonów pasażerskich,

- naprawy i modernizacje elektrycznych zespołów trakcyjnych,

- produkcja specjalistycznych wagonów towarowych.

PESA doskonale wykorzystała szansę związaną z bardzo dynamiczną liberalizacją przewozów towarowych w Polsce. Z powodu przyjętej przez PKP Cargo (narzuconej niejako odgórnie przez PKP S.A.) strategii osłabiania prywatnej konkurencji poprzez utrudnienie doposażenia jej w tabor, który państwowemu przewoźnikowi jest zbędny, wycofane z eksploatacji w PKP Cargo lokomotywy są odstawiane i złomowane. Prywatni przewoźnicy, chcąc utrzymać bądź rozwijać swą działalność, muszą zaopatrywać się w używany tabor poza granicami Polski (np. w Estonii, Czechach, Niemczech, Austrii czy na Słowacji). PESA w znaczącym stopniu zajęła tę niszę rynku, oferując prywatnym operatorom modernizację i ,polonizację" (dostosowanie konstrukcji do polskich przepisów w zakresie eksploatacji i bezpieczeństwa ruchu kolejowego) lokomotyw spalinowych sprowadzanych z innych państw.

Od 2006 roku firma rozpoczęła działania na rzecz pozyskania odbiorców w krajach Unii Europejskiej. Jest to wynikiem niespełnionych oczekiwań wobec tempa rozwoju rynku rodzimego (zamawiane przez samorządy oraz krajowych operatorów serie są krótkie - od 1 do kilkunastu pojazdów). Ważnym wydarzeniem dla firmy było zwycięstwo w przetargu na dostawę 23 trzyczłonowych, spalinowych zespołów trakcyjnych zamówionych przez Region Apulia (Ferrovie del Sud Est), w którym pokonała wszystkich wiodących producentów taboru kolejowego na świecie (m.in. Alstom, Bombardier, Steadler). Pierwsze wyprodukowane pojazdy ATR 220 zostały już przekazane do Włoch w wyznaczonym terminie.

Obecnie firma zatrudnia ponad 2500 osób, a więc w tym parametrze zbliża się do poziomu sprzed transformacji gospodarczej. Jej zamierzenia strategiczne koncentrują się głównie na powiększaniu udziału w rynku producentów taboru kolejowego w Polsce oraz zdobywaniu kolejnych zamówień poza granicami kraju na pociagi i tramwaje. Firma przygotowuje się również do wejścia w segment zespołów trakcyjnych klasy „intercity” (podwyższony komfort jazdy, prędkość 160-220 km/h) - PESA w konsorcjum z Bombardier Transportation Sweden AB bierze udział w procedurze przetargowej na zakup przez PKP Intercity 20 składów zespolonych. Strategicznym posunięciem było przejęcie latem 2008 r. ZNTK Mińsk Mazowiecki, ważnego na kolejowej mapie Polski ośrodka napraw i modernizacji taboru spółek PKP Przewozy Regionalne i Koleje Mazowieckie, a w przyszłości prawdopodobnie także PKP Intercity oraz SKM Warszawa.

Dotychczasowe efekty restrukturyzacji PESA potwierdzają, że we współczesnej gospodarce warunkiem rynkowego powodzenia przedsiębiorstwa (sprzedaż wyrobów z zyskiem w kraju i za granica) jest przyjęcie określonej strategii, czyli sposobu postrzegania przez przedsiębiorstwo otoczenia zewnętrznego, determinującego perspektywę i zasady jego działania. Ważnym elementem tej strategii jest wzrost zaangażowania przedsiębiorstwa na rynkach zagranicznych, początkowo dzięki wykorzystaniu przewagi konkurencyjnej uzyskanej na rynku krajowym - produkty PESA w skali rynku europejskiego charakteryzują się korzystną relacją jakości do ceny. 


\section{Literatura}

Biega S., Majewski J., 2004, Samorzqdowe autobusy szynowe. Podsumowanie pierwszego roku eksploatacji, Rynek Kolejowy, nr 4, s. 40-44.

Faryna P., 2004, Grzech główny - brak polityki transportowej. Rozmowa z prezesem zarzqdu PESA SA Tomaszem Zaboklickim, Rynek Kolejowy, nr 4, s. 3-5.

Grzegorzewicz K., 2006, Odtworzyć przemyst taborowy. Rozmowa z prezesem zarzadu Pojazdy Szynowe PESA Bydgoszcz Tomaszem Zaboklickim, Rynek Kolejowy, nr 5, s. 8-9.

Klimkiewicz J., 2008, PESA wygrywa europejskie zamówienia, Rynek Kolejowy, nr 1, s. 38-39.

Małachowski K., 2006, Polskie szynobusy jako alternatywa dla kolei lokalnych, Prace Komisji Geografii Komunikacji PTG, nr 12, Warszawa-Rzeszów, s. 149-162.

Pełka B., 1992, Polityka przemysłowa, strategia i restrukturyzacja przedsiębiorstwa, IOiZwP Orgmasz, Warszawa.

Rydzyński P., Klimkiewicz J., 2005, Producenci i zakłady naprawy taboru kolejowego w Polsce. Raport, Rynek Kolejowy, nr 1, s. 16-28.

Rydzyński P., 2008, Elektryczne zespoty trakcyjne i autobusy szynowe w Polsce 2008. Raport, Rynek Kolejowy, nr 6, s. 10-32.

Stryjakiewicz T., 2001, Orientacje teoretyczno-metodologiczne w geografii przemystu a transformacja gospodarki, [w:] Z. Zioło red., Problemy przemian struktur przemysłowych w procesie wdrażania regut gospodarki rynkowej, Warszawa-Kraków-Rzeszów, s. 13-27.

Wielądek A., 2008, PESA - Pewna Ekstra Spótka Akcyjna, Rynek Kolejowy, nr 6, s. 44.

Zaboklicki T., 2005, Złośliwe blokowanie przetargów?, Rynek Kolejowy, nr 9, s. 20.

Źródła internetowe (stan na listopad i grudzień 2008 r.)

www.inforail.pl;

Orłowski K., 2007, Nowoczesny tabor: jakość na szynach, www.wnp.pl, Wirtualny Nowy Przemysł: Portal Gospodarczy, artykuł z dnia 26.09.2007 (http://www.wnp.pl/artykuly/nowoczesny-taborjakosc-na-szynach,3900.html);

www.pesa.pl;

www.wikipedia.pl (pl.wikipedia.org) - hasła: „lista wagonów silnikowych PKP”, „lista zespołów trakcyjnych PKP"

\section{Restructuring of the Polish rolling stock industry: the example of Pojazdy Szynowe PESA Bydgoszcz SA enterprise}

This paper deals with the problem of restructuring the Polish rolling stock industry, presented on the example of PESA Bydgoszcz SA. In the previous economic system, the company was one of several dozen Polish State Enterprise Rolling Stock Repair Factories, strictly dependent on Polish National Railways (PKP). The main objective of its activity was repair of steam and diesel locomotives and freight cars, only for PKP. In result of technological, organizational and ownership transformations, the company has become the main Polish manufacturer of passenger rolling stock, especially rail-buses, electric units and trams. Moreover, PESA has improved its position in the Polish rolling stock repair and modernization market, by expanding the offer related to electric units and passenger cars. Achieving the leading position in Poland became a component of the strategy, based on entering European markets. 
dr hab. Andrzej Wieloński, prof. UW

Uniwersytet Warszawski

Wydział Geografii i Studiów Regionalnych

Zakład Geografii Miast i Organizacji Przestrzennej

e-mail: awielons@uw.edu.pl

mgr Marek Chmurski

Uniwersytet Warszawski

Wydział Geografii i Studiów Regionalnych

Zakład Geografii Miast i Organizacji Przestrzennej

e-mail: m.chmurski@student.uw.edu.pl,chmurski.marek@wp.pl 